\title{
Granulomatous Inflammation in a Patient with ALK-Negative Anaplastic Large Cell Lymphoma
}

\author{
ALK-Negatif Anaplastik Büyük Hücreli Lenfomalı Bir Hastada Granülomatöz Enflamasyon
}

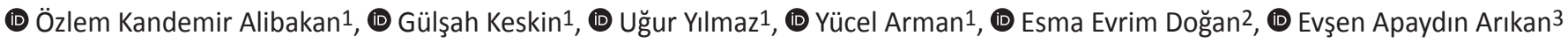

1 University of Health Sciences Turkey Prof. Dr. Cemil Taşçığlu City Hospital, Clinic of Internal Medicine, Istanbul, Turkey

2University of Health Sciences Turkey Prof. Dr. Cemil Taş̧̧ığlu City Hospital, Clinic of Hematology, Istanbul, Turkey

3istanbul University istanbul Faculty of Medicine, Department of Pathology, Istanbul, Turkey

\section{To the Editor,}

Granulomatous reactions are responses that can occur with many infectious, toxic, allergic, autoimmune, and neoplastic etiologies [1]. They occur as a result of immune cell activation due to a resistant stimulus that cannot be broken down. Hodgkin lymphomas are more commonly associated with granulomatous reactions, which is very unusual [2]. However, little is known about granulomatous reactions in cases of anaplastic large cell lymphoma (ALCL) [3]. Here we report a case of anaplastic lymphoma kinase (ALK)-negative ALCL presented with granulomatous reaction in the bone marrow.

A 44-year-old male presented with a 6-week history of fever and night sweats. He had no history of trauma or injections. Physical examination revealed hepatosplenomegaly and cervical, inguinal, and axillary lymphadenopathy. The examination revealed no insect bites, foreign body or inflammatory reactions, tattoos, or epilation. Laboratory results showed pancytopenia. TORCH, Epstein-Barr virus, VDRL, anti-HIV, HbsAg, anti-HCV, and Brucella titers were negative. Portal vein Doppler ultrasonography revealed no evidence of thrombosis. The echocardiogram was normal. Neck, chest, and abdominal computed tomography (CT) showed widespread lymphadenopathy. The bone marrow (BM) trephine biopsy showed non-necrotizing granulomas and moderate T lymphocytosis (Figure 1a). No atypical cells were found. The patient was admitted for further work-up. Laboratory findings included a white blood cell count of 1970/ $\mathrm{mm} 3$, hemoglobin of $11.4 \mathrm{~g} / \mathrm{dL}$, platelet count of $119000 /$ $\mathrm{mm} 3$, lactate dehydrogenase of $268 \mathrm{U} / \mathrm{L}$, ferritin of $170 \mathrm{ng} / \mathrm{mL}$, ACE negativity, and c-ANCA positivity. In the chest CT, there was no radiological evidence of sarcoidosis or tuberculosis. Paranasal sinus CT and nasal mucosal biopsy were negative for granulomatous polyangiitis. Beta-glucosidase leukocyte levels were normal, which excluded Gaucher disease. Rectal biopsy was negative for amyloidosis. The BM trephine biopsy sample was sent to an advanced pathology center for a second opinion and they confirmed the diagnosis. Since the patient was suspected of malignancy, the excisional biopsy of a 19-mm inguinal lymph node was performed (SUV $\mathrm{max}: 9.79)$. Analysis of the specimen revealed that the lymph node architecture was effaced by an atypical lymphoid infiltration, which consisted of scattered large atypical cells admixed with small lymphocytes and histiocytes. Non-necrotizing granulomas were observed in the soft tissue adjacent to the lymph node. Detailed morphologic and immunophenotypic features are presented in Figures 1b$1 \mathrm{~d}$. The findings were consistent with ALK-negative ALCL. The patient was then admitted to the hematology unit and an appropriate chemotherapy regimen was begun.

In cases of systemic ALCL, patients typically present with fever, painless but rapidly progressive peripheral lymphadenopathy, night sweats, and weight loss [4]. In our case, we aimed to show that a granulomatous reaction in the BM seen in a patient with systemic symptoms, pancytopenia, and lymphadenopathy may be associated with underlying ALCL. The co-occurrence of lymphoma and granulomatous reactions is exceedingly rare; however, pathologists and clinicians should be aware of this rare association in terms of differential diagnosis [5]. In this context, if a granulomatous etiology cannot be discovered, malignancy

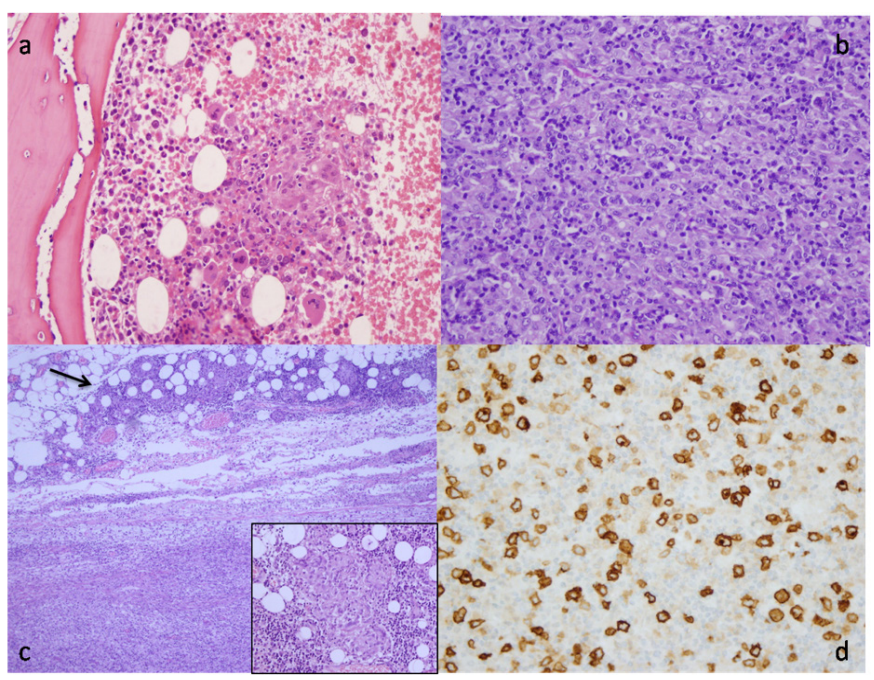

Figure 1. a) Non-necrotizing granulomas and moderate T lymphocytosis. b-d) Morphologic and immunophenotypic features consistent with anaplastic lymphoma kinase-negative anaplastic large cell lymphoma. 
should be excluded, as the underlying cause may be lymphoma in a very small group of patients. Although Hodgkin lymphoma is the most common lymphoma associated with granulomatous reactions, the possibility of non-Hodgkin lymphomas such as ALCL should not be overlooked.

Keywords: Granulomatous inflammation, Anaplastic lymphoma kinase-negative, Anaplastic large cell lymphoma

Anahtar Sözcükler: Granülomatöz enflamasyon, ALK negatif, Anaplastik büyük hücreli lenfoma

Informed Consent: Verbal and written informed consent was obtained from the patient.

\section{Authorship Contributions}

Concept: Ö.K.A., G.K., U.Y., Y.A., E.E.D., E.A.A.; Design: Ö.K.A., G.K., U.Y., Y.A., E.E.D., E.A.A.; Literature Search: Ö.K.A., G.K., U.Y., Y.A., E.E.D., E.A.A.; Writing: Ö.K.A., G.K., U.Y., Y.A., E.E.D., E.A.A.

Conflict of Interest: No conflict of interest was declared by the authors.
Financial Disclosure: The authors declared that this study received no financial support.

\section{References}

1. Brincker H. Interpretation of granulomatous lesions in malignancy. Acta Oncol 1992;31:85-89.

2. Sacks EL, Donaldson SS, Gordon J, Dorfman RF. Epithelioid granulomas associated with Hodgkin's disease. Clinical correlations in 55 previously untreated patients. Cancer 1978;41:562-567.

3. Genovese F, Becchina G, Nagar C, Gabriella O, Giacalone B, Canciglia R, Tralongo V. Anaplastic large cell lymphoma mimicking a necrotizing granulomatous lesion: a case report. Med J Clin Trials Case Stud 2017;10:11.

4. Nguyen KA, Su C, Bai HX, Zhang Z, Xiao R, Karakousis G, Zhang PJ, Zhang G. Disease site as a determinant of survival outcome in patients with systemic anaplastic lymphoma kinase positive anaplastic large cell lymphoma with extranodal involvement: an analysis of 1306 cases from the US National Cancer Database. Br J Haematol 2018;181:196-204.

5. Wu CY, Wang RC, Chen BJ, Chen WY, Jhuang JY, Chang MC, Wu YH, Nakada N, Karube K, Chuang SS. Granuloma with an underlying lymphoma: a diagnostic challenge and a wider histologic spectrum including adult T-cell leukemia/lymphoma. Appl Immunohistochem Mol Morphol 2020;28:316324.

๑Copyright 2022 by Turkish Society of Hematology

Turkish Journal of Hematology, Published by Galenos Publishing House

Address for Correspondence/Yazışma Adresi: Özlem Kandemir Alibakan, University of Health Sciences Turkey Prof. Dr. Cemil Taşçığlu City Hospital, Clinic of Internal Medicine, İstanbul, Turkey Phone : +905556842045

E-mail : ozlemkndmr91@gmail.com ORCID: orcid.org/0000-0002-5452-6273
Received/Geliş tarihi: June 12, 2021 Accepted/Kabul tarihi: November 9, 2021

DOI: 10.4274/tjh.galenos.2021.2021.0367 